\title{
obituary
}

\section{David Tidmarsh}

A pioneer of the modern forensic psychiatrist and former consultant psychiatrist at Broadmoor Special Hospital, Crowthorne, Berkshire

David Tidmarsh was born on 29 December 1932 at Orpington, Kent, into a prosperous middle-class family. Early on he showed clear evidence of his superior intelligence by winning scholarships from his preparatory school to Oundle Public School and then to Christ's College, Cambridge.

At Cambridge he read medicine, completing his clinical studies at 'Barts': he graduated MBBChir in 1958. The necessary house jobs he did at hospitals in Norwich and Maidenhead, during which time he met and married Marlen, a physiotherapist. His mandatory National Service he carried out in Malaya in the Royal Army Medical Corps. He was demobbed in 1961 with the rank of captain

Back in 'civvy street', he found himself jobless and strapped for cash. It was then, driven more by expediency than inclination, that he applied for and succeeded in filling an assistant medical officer job at Horton Mental Hospital, Epsom, Surrey: rarely has such a brilliant career had such 'inconspicuous beginnings'

It is important to stress the dramatic change at that time in the ethos of Horton as a result of the implementation of the Mental Health Act 1959. Instead of the run-of-the-mill mental hospital patients, Horton was obliged to admit an

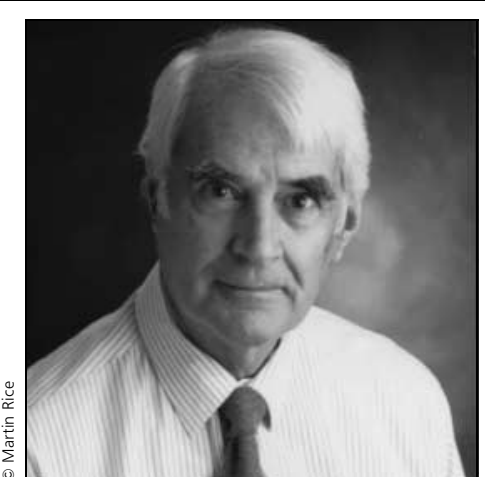

increasing number of offenders, particularly males. Fortuitously, forensic psychiatry began to dominate the work and fascinate the doctors, an opportunity which I, David and others grasped with both hands. In 1962 David took and passed the DPM (Eng).

David worked with me on the male side at Horton until 1973, apart, that is, for breaks when he was encouraged to gain specialist experience elsewhere. The first such experience, for 1 year, was at Belmont Hospital, Sutton, Surrey, a prime hospital for the treatment of the neuroses. The second was for 2 years at the prestigious Maudsley Hospital, London. Here, he joined a team headed by the eminent Professor John Wing. The team looked into the psychiatric aspects of homelessness in men, and David's personal involvement in this project was the basis of a thesis accepted by Cambridge for his MD in 1977

However, there is no doubt that his consultancy at Broadmoor was his core work. He arrived there at a time when the hospital was undergoing a seismic transformation, from a backward, quasi-prison, no-hope institution into a modern psychiatric hospital, staffed and equipped accordingly. David made an invaluable contribution to the work in hand. Apart from the complex clinical responsibility he shouldered, he served, at various times, as Chairman of the Medical Advisory Committee, Deputy Medical Director and Director of Research and had responsibility for medical audit.

Despite his pooh-bah responsibilities, he found time to enjoy a number of extracurricular activities, for example with the National Schizophrenia Fellowship and the Mental Health Foundation. Mention must also be made of his academic appointments, for example that of Senior Lecturer in Forensic Psychiatry at the Institute of Psychiatry and Examiner for the Diploma of Forensic Psychiatry.

He was a prolific writer: editors competed to get him to contribute chapters in books, single-author papers, memoranda and book reviews.

However, his most important appointment after his retirement was to serve on the Parole Board, not for the customary 3 years but for 6 years - a Herculean achievement.

A fitting bouquet was presented to him by the Royal College of Psychiatrists in 1992: as a token of appreciation of his valuable services to psychiatry and to the College itself. The College elected him FRCPsych (honoris causa).

David died of cancer of the colon on 9 July 2007. He is mourned by his devoted wife, Marlen, his daughters, Marie-Louise and Olivia, and a host of friends and colleagues.

Henry R. Rollin

doi: 10.1192/pb.bp.107.017749 